\title{
Cikkismertetés: Globális cselekvési terv a táplálkozási problémák és a klímaváltozás ellen
}

\author{
Article review: Global action plan against malnutrition and climate change
}

Ismertető: $\quad$ Bíróné Asbóth Katalin $₫$

Heim Pál Országos Gyermekgyógyászati Intézet, Módszertani lgazgatóság, Budapest

Ismertetett cikk: Swinburn BA, Krakk VI, Allender S, et al. The Global Syndemic of Obesity, Undernutrition, and Climate Change: The Lancet Commison report. Lancet. 2019 Feb 23;393(10173): 791-846. doi: 10.1016/S0140-6736(18)32822-8

Beküldve: $\quad$ 2019. 06. 07.

doi: $\quad$ 10.24365/ef.v60i4.484

Kulcsszavak: helytelen táplálkozás; bolygónk egészsége; klímaváltozás; gazdasági teher

Keywords: malnutrition; planetary health; climate change; economic burden

A helytelen táplálkozás - elhízás, alultápláltság és egyéb táplálkozási kockázatok - jelentik világszerte a legtöbb betegség rizikófaktorát. A klímaváltozás világszerte ugyancsak jelentős hatással van az emberi egészségre és a természeti környezetre is. Ezek a tényezők egymást felerősítő hatással bírnak, melyet a szinergia (együtthatás) és epidémia (járvány) kifejezések összevonásával szindémiának (syndemic), együttes világjárványnak (global syndemic) neveztek el. Mind a helytelen táplálkozás (elhízás, hiányos táplálkozás és alultápláltság), mind pedig a klímaváltozás, és az abból származó káros környezeti hatások súlyos helyi és világgazdasági következményeket okoznak.

A táplálkozással összefüggő problémákat az elmúlt 30 évben nem sikerült sem eredményesen kezelni, sem javulást elérni, a (szak)politikai tehetetlenség és a gazdasági érdekek eltérő volta miatt. A The Lancet-bizottság (továbbiakban: Bizottság) arra jutott, hogy a három jelenség komoly egymásra hatása és együttes hatásai miatt a megoldásokat is együtt kell kidolgozni. A klímaváltozás és táplálkozási problémák összekapcsolásával közös keretrendszer kidolgozására van szükség és lehetőség.

A Bizottság ajánlásában kulcsüzeneteket (key message) fogalmaz meg. Részletesen ismertetésre kerülnek a főbb alapfogalmak és problémakörök, illetve több kiemelt szövegrész (panel) szól egyes kérdések gyakorlati összefüggéseiről.

Az elhízás, alultápláltság és a klímaváltozás egyidejű globális jelenléte, biológiai, pszichológiai és szociális kölcsönhatásaik azt igénylik, hogy egyidejúleg és párhuzamosan kezeljék őket kettős (double-duty) vagy hármas (triple-duty) akciók keretében. Az ajánlás 9 átfogó célra és 20-nál több akcióra tesz javaslatot. A javaslatok között szerepel a nemzetközi és országos kormányzati iránymutatások, megoldási tervek és megállapodások kidolgozása az együttes világjárvány enyhítésére. Ugyancsak szorgalmazzák a helyi, azaz önkormányzati szintű cselekvéseket a lakosság mozgósítására. Ajánlásuk szerint erősíteni kell az olyan civil szervezetek szerepét, amelyek elkötelezettek a változások véghezvitelében. Szükséges a kereskedelmi érdekek befolyásának csökkentése a következő generációk egészsége érdekében, valamint fenntartható és egészséget támogató üzleti modelleket kell kidolgozni. További tudományos kutatásokra van szükség, melyek a hatékony beavatkozások érdekében feltárják a világjárvány meghatározó és befolyásoló tényezőit. Az ajánlásban 5 domináns hajtóerőt (dynamic) azonosítanak: a kormányzati (governance), az üzleti (business), a szolgáltatási és szükségleti (supply and demand), ökológiai (ecological), és az emberi 
egészségi (human health) visszajelző hurokrendszert (feed-back loop). A cikkben személetes ábrák mutatják be az összefüggéseket az együttes világjárvány egyes összetevői, azok szintjei és a fő hajtóerők között. [1. ábra]

Az elhízás világszerte növekvő aránya, a helytelen táplálkozással járó kockázat, a táplálkozással összefüggő betegségek és a halálozás egyaránt érinti a fejlődő és fejlett országokat. Az ökológiai változások (pl. a termőhelyek csökkenése, a termesztési feltételek romlása, a környezeti és időjárási katasztrófák, stb.) előrevetítik az előállított élelmiszer minőségének és mennyiségének jövőbeni drasztikus változását. Az együttes világjárvány alkotóelemeinek egymásra hatása, az egészségromlásból, környezeti károkból adódó gazdasági terhek sürgős változást kívánnak a társadalmi működés, az emberi gondolkodás és a cselekvés minden szintjén.

\section{1. ábra: A rendszerek és következmények keretrendszere}
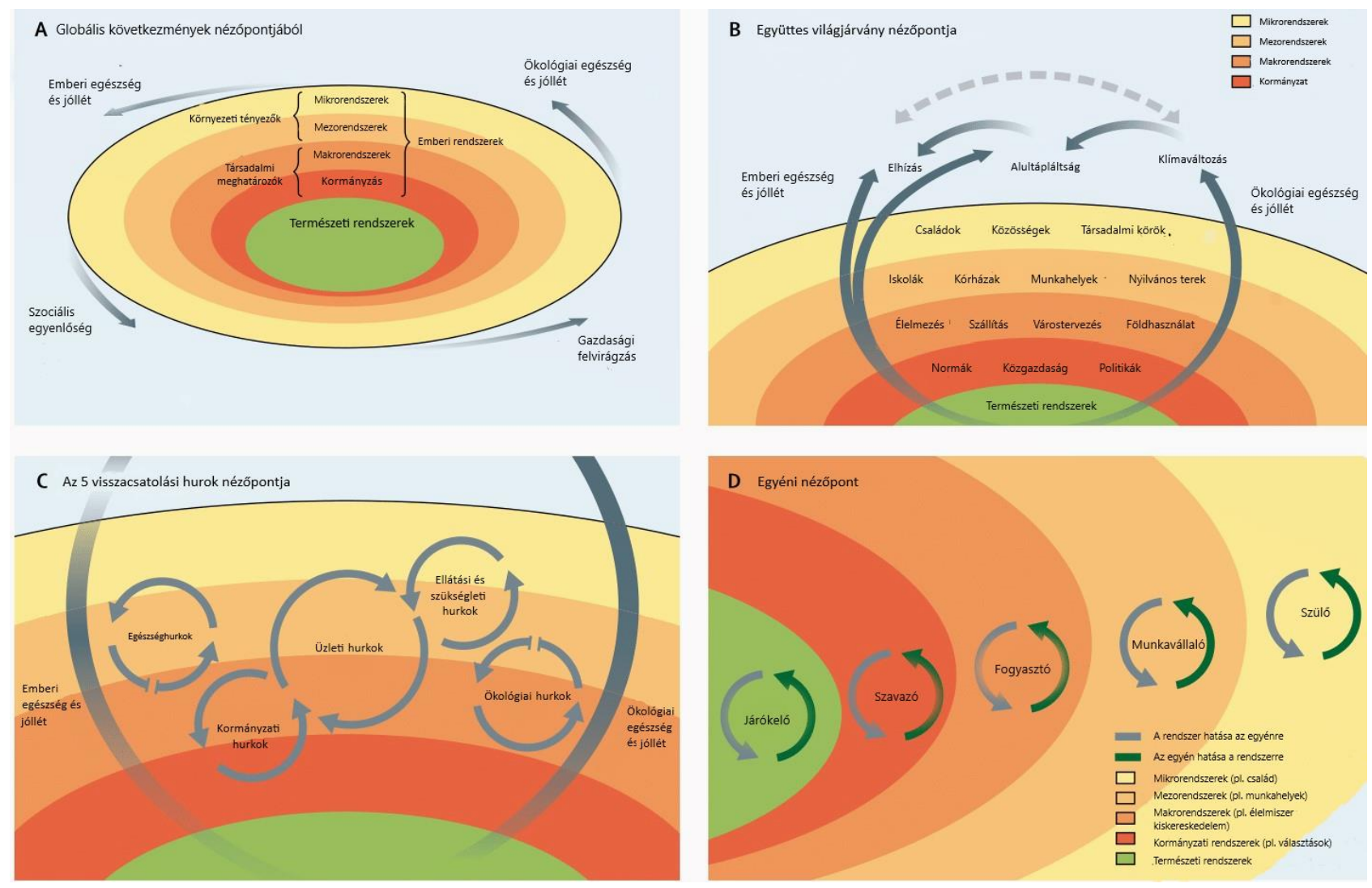

Forrás: az eredeti ábra magyar változata

\section{TANULSÁGOK HAZAI SZAKEMBEREK SZÁMÁRA}

Az elhízás, alultápláltság és a klímaváltozás világméretű egészségi és ökológiai válságot idéz elő, melynek hatása alól egyetlen ország, vagy kontinens sem mentesül. Csak a társadalmi, gazdasági és egyéni életben történő jelentős szemlélet-, fogyasztási- és életmódváltással tehetünk hatékonyan a folyamatok felgyorsulása és súlyosbodása ellen. A szemléletváltásban az egészségügy és az oktatás szereplőinek is kulcsszerepe kell, hogy legyen. 